\title{
Imperial dream: the RILA as achievement of the second reign's diplomatic objective for Paraguay
}

\author{
Sonho imperial: a RILA como concretização do objetivo diplomático do segundo \\ reinado para o Paraguai
}

\section{Sueño imperial: Ia RILA como realización del objetivo diplomático del segundo reinado para el Paraguay}

\author{
Luiz Jeha Pecci de Oliveira ${ }^{1}$ \\ Gabriela Oshiro Reynaldo ${ }^{1}$ \\ Maria Augusta de Castilho ${ }^{1}$
}

Received on 30 June 2021; revised and approved on 17 Sept. 2021; accepted on 13 Oct. 2021

DOI: http://dx.doi.org/10.20435/inter.v22i4.3422

\begin{abstract}
This work has the purpose of presenting the Latin American Integration Route (RILA) as the achievement of diplomatic objectives already traced in the Brazilian imperial era between itself and Paraguay. This paper will show how, in the diplomatic field, the Empire can be qualified as the historical period which designed Brazil, fixing it as a regional power and positioning itself in the way of ensuring policies whose consequences would be beneficial even for its neighbors. The border relations between Brazil and Paraguay will be treated with its peculiarities, besides a description of the region's hydrography with regards to the River Plate Basin. So, this work will enter in its historical part by analyzing the formation of the Brazilian Empire's Second Reign, explaining its development and characteristics that interest to this paper, presenting its diplomatic conceptions, showing the problems faced by the tropical monarchy in the Platine Region and the objectives and paths searched to bypass them. In the end, it will be brought to analysis the idea of the RILA and its Latin American integration project, with investments aiming to use the region's hydrography to export local products, linking it with the geopolitical objective searched since imperial times to guarantee the free access to the Platine rivers. This research utilized qualitative methodology, analyzing books and articles in the area to base the central thesis. The result achieved met the original goal, showing that the RILA comes from the development of a conception of foreign relations created, for Brazil, in the Monarchy. Keywords: border Brazil-Paraguay; River Plate Basin; Brazilian Empire; diplomacy; RILA.

Resumo: Este trabalho tem o objetivo de apresentar a Rota de Integração Latino-Americana (RILA) como concretização de objetivos diplomáticos já traçados na época imperial do Brasil para as relações entre ele e o Paraguai. Este artigo mostra como, no campo diplomático, o Império pode ser qualificado como o período histórico que pensou o Brasil, fixando-o como potência regional e se posicionando para garantir políticas cujas consequências fossem benéficas mesmo para seus vizinhos. É abordada a relação fronteiriça entre Brasil e Paraguai com suas peculiaridades, além da descrição sobre a hidrografia da região no que tange à Bacia do Rio da Prata. Então, o artigo adentra na parte histórica ao analisar a formação do Segundo Reinado do Império do Brasil, explicando seu desenvolvimento e características que interessem a esse artigo, apresentando suas concepções diplomáticas, mostrando os problemas enfrentados pela monarquia tropical na região platina e os objetivos e caminhos buscados para contorná-los. Por fim, é trazida para análise a ideia da RILA e seu projeto de integração latino-americano, com investimentos visando a utilizar a hidrografia da região para escoar os produtos locais, correlacionando-a com o objetivo geopolítico buscado desde a época do Império de garantia de livre acesso aos rios platinos. Esta pesquisa utilizou metodologia qualitativa, com análise de livros e artigos da área para embasarem a tese central. O resultado atingido atendeu ao objetivo buscado, mostrando que a RILA provém do desenvolvimento de uma concepção para relações exteriores criada, para o Brasil, no período monárquico.
\end{abstract}

Palavras-chave: fronteira Brasil-Paraguai; Bacia do Prata; Brasil Império; diplomacia; RILA.

Resumen: Este trabajo tiene como objetivo presentar la Ruta de Integración Latinoamericana (RILA) como una realización de objetivos diplomáticos ya delineados en el período imperial de Brasil para las relaciones entre él y Paraguay. Este artículo mostrará cómo, en el campo diplomático, el Imperio puede calificarse justamente como el período histórico que pensó Brasil, estableciéndolo como una potencia regional y posicionándose para garantizar políticas cuyas consecuencias serían beneficiosas incluso para sus vecinos. Se abordará la

\footnotetext{
${ }^{1}$ Universidade Católica Dom Bosco, Campo Grande, Mato Grosso do Sul, Brasil.
} 
relación fronteriza entre Brasil y Paraguay con sus peculiaridades, así como una descripción de la hidrografía de la región, con respecto a la Cuenca del Río de la Plata. Luego, el artículo entrará en la parte histórica analizando la formación del Segundo Reinado del Imperio de Brasil, explicando su desarrollo y características que interesan a este artículo, presentando sus concepciones diplomáticas, mostrando los problemas que enfrentaron la monarquía tropical en la región platina y los objetivos y caminos perseguidos para sortearlos. Finalmente, se llevará a análisis la idea de RILA y su proyecto de integración latinoamericana, con inversiones orientadas a utilizar la hidrografía de la región para el transporte de productos locales, correlacionándola con el objetivo geopolítico perseguido desde la época del Imperio garantizando libre acceso a los ríos platinos. Esta investigación utilizó una metodología cualitativa, con análisis de libros y artículos del área para sustentar la tesis central. El resultado alcanzado cumplió con el objetivo buscado, mostrando que RILA proviene del desarrollo de un concepto de relaciones exteriores creado para Brasil durante el período monárquico.

Palabras clave: frontera Brasil-Paraguay; Cuenca del Plata; Imperio del Brasil; diplomacia; RILA.

\section{INTRODUCTION}

In the last years, South America has become an attractive pole for international investments, which is the reason why a more detailed study about such economic growth became relevant. In this way, the Latin American Integration Route (RILA) presents itself as a way to achieve the economic development in the region, starting from a local integration project which was being drawn since the times of Imperial Brazil.

So, the present paper proposes to analyze the RILA as an integration mechanism of the Latin American countries, specifically those of the Platine Basin, focusing on the historical and geographical relation between Brazil and Paraguay. To do this, the adopted methodology consisted of searches in scientific works and thematic books, with later qualitative data analysis, having this study an eminently qualitative nature.

At the first moment, the Platine geography which includes Brazil and Paraguay will be characterized, referring to the first approaches between the nations and the obstacles that involved their integration process.

Later on, this work will bring historical data about the Second Reign of the Brazilian Empire (1840-1889), dealing with the imperial external politics in the Platine Basin, which made itself of utmost importance for the relations between Brazil and Paraguay, as many concepts of the imperial diplomacy for the region were the keys to regional integration.

In the end, this paper will bring general aspects about the RILA, with emphasis in the regional development idea by such an audacious project, correlating it with the accomplishments of the Brazilian diplomatic objectives traced since the times of the monarchy.

This study does not aim to exhaust the academic debates about such topics, mainly because the RILA brings novelties to the border dialogues, being an attribution of science to keep up with such transformations and propose relevant reflections that contribute to the regional development.

\section{REGIONAL GEOGRAPHY}

To have an amplified knowledge about the geography of Paraguay, its territorial aspects will be brought up, that is, the border limits and its hydrography, which is of great economic importance for the country. Another factor that deserves focus are the particularities in the border, which influences the region's own customs. Also, another border standard related to consumption at various local points has been created, the most famous the places being those 
of Ciudad del Leste and Pedro Juan Caballero, and that moves a big flow of people at both sides of the border.

In the first place, it needs to be remembered that the Republic of Paraguay is located at the center of the South American continent, bordering Brazil at northeast, Bolivia at north and west and Argentina at south and west.

A curious fact is that Paraguay is one of the two countries of South America that is landlocked, together with Bolivia. This is a factor that influences directly the geopolitics and the Human Development Index of Paraguay, because it is an economic hamper.

Once exposed these facts, quite succinctly, an analysis about the borders and hydrography of Paraguay needs to be done, making a comparison with the particularities of the border area, especially with the Brazilian state of Mato Grosso do Sul.

\subsection{Description of the term "border"}

Although commonly known, the term "border" hasn't always received the due attention of the academy. According to Paixão (2006), only in the 1990s the subject started to be studied in a more incisive way. However, the author warns that there are still gaps in relation to studies on the subject.

In Brazil, the Federal Constitution (BRASIL, 1988) sets a particular regime for the border strip, since such spaces are of paramount importance for the defense of the national territory, given that Brazil has a large border strip, and has the most diverse forms of limits, whether water, road or sea. Focusing on how the border between Brazil and Paraguay is organized, the particularities that occur in cities where they have a dry border will be demonstrated, as in the case of the border between the city of Ponta Porã, at the Brazilian state of Mato Grosso do Sul, and Pedro Juan Caballero, at the Paraguayan department of Amambay.

One cannot fail to demonstrate that the consumption of yerba mate as terere was a custom absorbed by Brazilians, and that it originated among the Paraguayans. Over time, this habit spread to other cities in Mato Grosso do Sul, despite not having as much representation in the rest of the country.

Another fact that deserves to be highlighted is that the border region is marked by a lot of social inequality. People who have an income live in better places, and those who don't are slaves to precarious housing. That is, "Like everywhere, the border's housing system varies, according to each person's resources. The poor live in small houses covered with mud and grass, built on small lots [...]" (SILVA, 2003, p. 83).

It turns out that the differences are even more striking, as there is a distinction between government exchange policies, in which Brazilian currency has a much greater value compared to Guarani, which is the currency used in Paraguay. In this way, the imbalance becomes even more evident, and gives the impression of a frontier full of poverty. The authors Souza and Gemelli corroborates this understanding, under the following terms:

The State's performance is different on each side of the border. In Paraguay, the politicaladministrative system has a centralized autonomy, while in Brazil, this autonomy is decentralized in each State of the Federation. Thus, there is, in Brazil, a greater role for the State in the territory than in Paraguay. This is one of the factors that contribute to the differentiation linked to the existing tourist infrastructure on the border between the two countries. (SOUZA; GEMELLI, 2011, p. 109). 
Finally, the fact is that the large border strip is still a very isolated place and difficult to inspect, which ends up facilitating the action of drug traffickers in its points. Silva (2003) establish that isolation, depopulation and lack of rapid communication and policing at the border contribute to this insecurity.

With regard to the border with Paraguay, although there is a greater number of border towns, as exemplified by the municipalities of Bela Vista, Paranhos, Coronel Sapucaia, Ponta Porã and others, most of these borders are dry and have twin cities, across the border.

An observation, which will be better explained in the next topic, deals precisely with the hydrographic characteristics of Paraguay, which are essential for a better understanding of international relations and Paraguay's economic insertion in the world. The La Plata Basin, which bathes the Guarani country, serves as a gateway for Paraguayan products to reach the sea through Brazil or Argentina, and be able to be exported to the rest of the world.

This brings to analysis the situation of the peculiar state of Mato Grosso do Sul. Its geography allows it to act as a link to the flows between the Pacific and Atlantic oceans, since it is located in the center of the continent, in addition to giving it the border condition.

Many municipalities in this Brazilian state are located on the border strip, some of them in semi-conurbation or conurbation with other municipalities in neighboring countries, which are the formation of sister cities, facilitating the circulation of people and materials, legal and illegal, composing a geography that must be worked on in terms of particularities and riches, even more so due to the fact that much of this strip is a dry frontier.

In this context, Becker (2007) contributes by teaching that the frontier needs to be understood as "[...] a space that is not fully structured and, therefore, potentially a generator of new realities [...]". Within the scope of border lessons, there is a frequent association of the term "region" with the term "border", generating the so-called "border region", marked by ethnic diversity and the action of two logics: the local and the global, which, indirectly, confront and complement themselves, combining in a potentially unique space.

Currently, when "frontier" is mentioned, several perceptions are revealed, and the media has a significant weight in the construction of perceptions about the mentioned term. Two images are commonly constructed: the first is associated with illicit acts on the border, given the fluidity of people and goods; and the second concerns consumer tourism, so that this same "consumption frontier" is not a decontextualized element, but materialized from the needs and interests of both countries involved (POLÓN, 2015, p. 76).

Given the above observations, it appears that the borders in the State of Mato Grosso do Sul with the countries of Bolivia and Paraguay have some divergences, but also many similarities, especially in the issue of economic and social differences, in addition to the large amount of dry frontier. In view of this reality, the existence of a consumption border with these countries was made possible, with the aim of favoring both sides, and trying to somehow promote the economy in this range.

In the next topic, it will be demonstrated how the hydrous aspects are beneficial and help Paraguay so much in trying to place its products in the world economy, since it is a landlocked country. 


\subsection{Hydrography and ground of Paraguay}

In order to understand why Paraguay is so dependent on its rivers to move its external economy, as well as for the production of its electricity, it is necessary to understand a little better the characteristics that the country has regarding its ground and hydrography.

Paraguay has a predominantly plain ground, characterized by the Chaco, in addition to being a country bathed by important rivers, which make the country part of the great La Plata Basin, which ends up uniting Brazil, Bolivia, Paraguay, Argentina and Uruguay.

Undoubtedly, the Paraguay River is the river with the greatest hydric and economic expression for the homonymous country, since it is navigable and allows the flow of its products to the oceans, so that they can be properly exported to European, African or Asian markets.

A fact that cannot go unnoticed is that the Paraguay River passes through several countries, since it originates in the State of Mato Grosso, in Brazil, and flows into the La Plata Basin. So, it is normal that regional and diplomatic tensions end up being created, as each country seeks to make its interests stand out. Thus, aiming at greater integration between the countries that make up the Rio de la Plata basin and seeking to reduce road costs, the interested nations decided to develop an efficient waterway for the export of products.

Thus, "By uniting the Platine countries, the waterway represented a historical and economic necessity, and should be the first step towards regional and continental integration [...]" (ZUGAIB, 2007 , p. 71). And with that focus, it ended up becoming something concrete. In order to clarify how much the waterway in the La Plata Basin favors the economy, integration and development of the regions that comprise it, Zugaib defends that the fluvial transport system:

It provides, through a considerable reduction in transport costs, an increase in competitiveness and the possibilities of exporting products from the region, thus encouraging the growth of regional economies and favoring the economic, political and social integration of the countries that are under its influence area. (ZUGAIB, 2007, p. 187).

That said, it is evident that the waterway ended up being beneficial to all the countries involved, so that it brought benefits that were not restricted to the economic field at regional levels, dealing, above all, with local development in general, a phenomenon that was well observed in the cities of Corumbá, in Brazil, and Porto Suarez, in Bolivia.

It can be concluded, therefore, that the Paraguayan ground is divided between small mountains and plains, and has important rivers in its territory, where even if they do not originate in Paraguayan territory, they provide navigation, helping to transport their production.

However, it should be remembered that South America is not yet fully integrated, especially with regard to the Platine region. Contemporary projects to overcome this challenge are already underway, but it is remarkable how they reflect geopolitical conceptions already developed in the formation of the Latin American nation-states themselves. The RILA, for example, which will be better described in the last chapter, reflects an integrative project on which the great statesmen of the Empire of Brazil were already meditating, notably those active since the times of the Second Reign. 


\section{THE IMPERIAL PROJECT IN THE PLATINE BASIN - THE RELATIONS BETWEEN BRAZIL AND PARAGUAY IN THE SECOND REIGN}

From the understanding of regional geography, the foundations on which the relations between Brazil and Paraguay are structured can also be understood. To better understand the current development context of the Bioceanic Route, however, a historical investigation is needed both about the formation of Brazil, in order to understand how Brazilian international policies were constructed, and about our contacts - not always harmonious - with the Guaraní country.

\subsection{The Second Reign of the Brazilian Empire (1840-1889)}

Understanding certain historical particularities of the formation of the Brazilian State is essential to get a glimpse the role sought by the country in its relations with its neighbors. Given the notoriously complex task of summarizing more than five centuries of national history in one chapter of an article, we chose to focus this work on bringing to light one of the most prolific periods of Brazilian development, marked by the emergence of great figures and the development of embryonic state policies that would mature in subsequent years - the Second Reign (1840-1889).

This work does not intend to go into the analysis of the issues that led to the fall of the Brazilian monarchy, but only to point to it as an essential moment for the emergence of national geopolitical conceptions that will lead to the development of the thesis.

The Brazil of the early nineteenth century was a newly founded nation and markedly distinct from its neighbors in South America, notably for being monarchic and Portuguese-speaking. The former colony of Portugal took advantage of the institutions left by the former Portuguese metropolis to take its first steps towards the formation of its own national state, in a process that began with its independence in 1822. On the formation of this state, João Camilo de Oliveira Torres brings a curious vision:

The independence of Brazil, however, was a legitimate revolution: It wanted to destroy nothing. Just to build. Brazil went from an absolute monarchy to a constitutional monarchy, from a United Kingdom to a sovereign nation, all thanks to the action of government instruments and institutions from the previous situation. In fact, Independence was the recognition, by the legal government of Brazil, of certain de facto situations of the "real country". (TORRES, 2017, p. 69).

However, the stability of the country was shaken by the circumstances. The tropical monarchy had experienced the early resignation of its first emperor, Pedro I, in 1831, caused by a political crisis aggravated by the erosion of its image driven by failures in foreign policy and economic problems deepened by the increase in government spending and the fall in the export value (FAUSTO, 1995). Due to the then-minority of the heir to the throne, which prevented him from assuming the government of Brazil, the latter began to organize itself around a group of regents.

The Regency Period (1831-1840) was marked by internal struggles and such political instability that it almost led to the territorial fragmentation of Brazil. In order to save the country's unity, an agreement between the various political factions of the time led to the acclamation of Dom Pedro II, then 14 years old, as Emperor of Brazil, anticipating his majority, as early as 1840 (CALMON, 2002). The historian Pedro Calmon, calling this phenomenon "monarchic reaction", expressed himself in this way about the reason that gave rise to it: 
Brazil had been fatigued by the incidents, the riots, the dramas of the regency, and the monarchical idea, propagated by the conservative classes, had returned to dominate the country. It was, of course, the reaction against eight years of a violent democratic experience, which had given rise to all the manifestations of national fragility and the lack of education of the masses. (CALMON, 2002, p. 214).

Before diving into the narrative about the development of the period that became known as "Segundo Reinado", it is interesting to dedicate a topic to the presentation of the new emperor of Brazil. The literate and cult precocious monarch received the following description from Oliveira Lima:

D. Pedro II is definitely placed among the main moral figures of the last century. His long reign, inaugurated by a parliamentary pronunciamiento and finished by a military pronunciamiento; his love of peace without dishonor and justice at all costs; his passion for the sciences, first, for the letters, then, and, finally, for the arts, in short, for everything related to the spirit; his contempt for vulgarities and detachment from riches; his dignified affability; its severity without arrogance; his unaffected goodness; his limitless honesty made the name of this monarch not only familiar to those concerned with history and politics, but also in philosophy and morals, more dear to those who allow themselves to be seduced by the superior aspects of humanity. His name is, after all, but fair, for he was the noblest of men and the most perfect of sovereigns. (OLIVEIRA LIMA, 2012, p. 203-4).

Calógeras (2009, p. 179) argues that Dom Pedro II put an end to "[...] the inherent instability and weakness of the provisional governments of the Regency". The same scholar (2009) still emphasizes the idea of national identification in the figure of the monarch, pointing out that, in the rebellions experienced in the regency, the revolting factions proclaimed that their "separations" would end as soon as the emperor reached the age of majority and began his government.

Thus, in Brazil, a level of institutional solidity was reached that would be decisive for imperial progress. João Camilo de Oliveira Torres (2017) argues that the Empire's politicians, notably during the Second Reign, managed to implement and make effective institutions suited to the country's conditions, in order to make the best use of the real possibilities of the national environment for the happiness of the people. In the same conclusive line, Pedro Calmon (2002) places industrial animation, economic growth and general prosperity as hallmarks of the time.

Once the internal political-economic stabilization was achieved, it was time for the Empire to seek regional hegemony in South America, which would not have been possible without facing its main border problems with its neighbors. And one of the regions that most concerned the monarchy was the La Plata Basin.

\subsection{THE EMPIRE'S FOREIGN POLICY IN THE PLATINE REGION}

Brazil has always been, in certain way, a prisoner of its own geography. The huge territory left by Portugal as a legacy to the new country when it gained independence was also quite depopulated and isolated. The foreign policy of the nascent tropical monarchy turned to mitigate the negative effects of these characteristics, with the first initiatives for national integration still being found in the Empire. One of the focuses of this policy was precisely the river of La Plata.

The province of Mato Grosso (which included the territory currently belonging to the States of Mato Grosso, Mato Grosso do Sul and Rondônia) was quite isolated, having regular access to its most important urban centers only by river, such as the city of Cuiabá. Furthermore, there 
was the problem of blurring the southern border of the province with Paraguay, which sought to establish the border to the Rio Branco, while Brazil was claiming possession of the territory between the Branco and Apa rivers (DORATIOTO, 2002).

What turned the Platine region into a focus of international tension was the crucial importance of its basin not only for Brazil, but also for all the other nations bordering it: Argentina, Uruguay and Paraguay. Barrio comments on this in the following words:

The rivers of the Platine Basin bathed all countries in the region and constituted the main means of communication and transport to the interior of the continent, the great commercial artery that fed local economies and drained their production, the most conspicuous natural accident to delimit the borders between the states. For Brazil, the Platine basin was the "umbilical cord" that united Mato Grosso and Rio de Janeiro and ensured its integration with the Empire; for Buenos Aires, it was the route of access and control over the Argentine coastal provinces; for Entre-Ríos and Corrientes and for Paraguay, it was their vital line of communication with the ocean and the outside world; for Uruguay, it was the raison d'être of its very existence. The actors of the platine system wanted, therefore, to ensure their free access to the full extension of the estuary, but they also intended, at the same time, to expand their control over the portions of water that were riparian to them, restricting the access of other platine states. (BARRIO, 2018, p. 122).

And continues:

Thus, while Argentina wanted to close the Rio de la Plata to other countries in the region, Paraguay intended to move freely along the Paraná River to its mouth, but resisted the pressures of the Empire for its vessels to navigate the waters of the Paraguay river, which crossed guaraní territory; Brazil advocated the full opening of the Plata, Paraná and Paraguay to free navigation, but it placed its own diplomacy in check when it adopted the opposite policy regarding the Amazon River, denying its access to foreign nations. The Imperial Government aspired to project its power to the banks of the Plata, which would have constituted, in the nation's imagination, the natural southern border of the island, Brazil, idealized since the colonial period; Paraguay aspired to expand outwards along the Plata, to seek its Lebensraum; Buenos Aires intended to close the River Plate and nationalize the Paraná River as an inland watercourse for the Argentine Confederation to guarantee national unity and try to subdue Paraguay and Uruguay. (BARRIO, 2018, p. 122-3).

These concerns, combined with the consequences of the processes of formation of national states in the Rio de la Plata, led to the outbreak of the Triple Alliance War (also known as the Paraguayan War), which opposed Paraguay to the coalition formed by Argentina, Uruguay and the Empire of Brazil, ending with an allied victory (DORATIOTO, 2002).

Shortly after the War of the Triple Alliance, the Empire signed with Paraguay the peace treaty of January 9, 1872, known as the Cotegipe-Loizaga Treaty, securing for itself a good part of the territory that is now part of the State of Mato Grosso do Sul (VARGAS, 2017). Doratioto (2014, p. 51) comments on this in the following terms:

The Paraguayan constitutional president (in 1870, a Constituent Assembly drafted the country's first Magna Carta), Salvador Jovellanos, proposed to the Baron of Cotegipe the start of separate peace negotiations. In February 1872, the Peace Treaties were signed; of Limits; Extradition and Friendship, Commerce and Navigation between Brazil and Paraguay. The Brazilian Empire then fulfilled its historic objectives in relation to Paraguay: the borders were defined in the terms pursued by Rio de Janeiro two decades ago - even restricting it to the Apa River, as traditional demand, instead of advancing to the Igurei, as established by the Treaty of the Triple Alliance - and the free navigation of international rivers in terms 
of International Law. These treaties also allowed the continuation, for an indefinite period, of the presence of Brazilian troops in Paraguayan territory. These military forces supported the control that imperial diplomacy exercised over Paraguay's internal policy, with the aim of preventing the Paraguayan government from being exercised by elements sympathetic to Argentina. In the following years, the Paraguayan rulers would rise to power and would remain in it with the tacit acceptance of the Empire. (DORATIOTO, 2014, p. 51).

The end of the Paraguay War brought devastating consequences for the Guarani country. Over the following decades, in the field of foreign policy, Paraguay became politically dependent on Brazil and economically on Argentina (YEGROS; BREZZO, 2013).

In any case, the performance of imperial diplomacy managed to achieve its goals, being described by Goes Filho (2013) as coherent, persistent, successful and admired even by its natural adversaries. The achievements of the Empire in the region of Prata are a good example of this. Having guaranteed the contact of the province of Mato Grosso with the rest of the country and keeping Paraguay under the influence of Rio de Janeiro, the work of hegemonic integration in the region through political and diplomatic channels was carried out.

All that remained was the economic integration of the country with its neighbors, with a real promotion of local development focused on these more isolated regions, and in partnership with neighboring countries. This was a question that remained unresolved for centuries, and which even the imperial cabinets could not resolve. However, in the 21st century, after the fall of the monarchy, integrative projects emerge that can finally solve this problem.

\section{THE RILA AS IMPLEMENTATION OF THE IMPERIAL INTEGRATION DREAM}

The Latin American Integration Route, popularly known as the Bioceanic Route, is located in the heart of South America, connecting its east coast (Atlantic Ocean) to the west coast of the Pacific Ocean, and encompassing, a priori, four nations: Brazil, Paraguay, Argentina and Chile. What is most striking in this scenario is the possibility of flowing Latin American production, as well as the economic approximation between the countries involved.

Therefore, the RILA arouses the interest of businessmen, government entities and the academic community itself, which, in turn, sees it as an important object of study for Latin American integration, especially in terms of regional development.

News regarding the construction of three bridges on the Brazil-Paraguay border has the potential to significantly accelerate several deals across the globe. In this sense, Sunakozawa and Reynaldo contribute to the discussion:

Among these constructions of border bridges, between Brazil and Paraguay, there is one that will be on the Paraná River, in the Marco das Três Fronteiras region, which will connect the city of Foz do Iguaçu, in the State of Paraná, Brazil, with the city of Presidente Franco, in the Department of Alto Paraná, Paraguay, this project is called the Second Border Bridge over the Paraná River (the first is the Ponte da Amizade linking the cities of Foz do Iguaçu, in Brazil, with Ciudad del Este, Department of the Upper Paraná, Brazil, Paraguay). A third bridge, also on the border of the two countries mentioned, will be on the Paraguay River, connecting the city of Porto Murtinho, in the State of Mato Grosso do Sul, Brazil, with the city of Carmelo Peralta, in the Department of Alto Paraguay. And, finally, a bridge across the same countries, over the Apa River, to link the Brazilian city of Porto Murtinho to the city of San Lazaro in the Department of Concepción. (SUNAKOZAWA; REYNALDO, 2019, p. 703-10). 
Given the magnitude of the works, economic eyes turn to RILA, such as investments in transport infrastructure (road and port), aimed at distributing raw materials to industries on all continents, given that, historically speaking, Latin American countries are characterized by exporting agrarian products.

In addition to the export sector, the tourism sector stands out, and it will probably have a notable growth in the coming years, given the fluidity that the routes will provide. In this logic, tourism presents itself as an activity that perfectly fits the capitalist logic, always managing to renew itself, generating several jobs and promoting a daily circulation of capital.

Several nations are already showing signs of relief in customs tariffs, as well as the signing of new trade agreements, even bringing RILA countries closer to countries in the strongest economic bloc today, the European Union.

The RILA is moving towards regional economic development, requiring a special academic look, and the same from government agents and civil society as well, since inhabitants of the cities involved in the routes will suffer direct impacts, whether in terms of economic growth, either with particularities that will possibly arise, such as interference in the health, education and security systems of cities.

No less important are the numerous legal implications that emerge, motivating legal studies on the part of academies on the subject, with a view to a possible harmonization of the legal norms of the countries involved, as warned by Sunakozawa and Reynaldo (2019).

Not restricted to taking advantage of the region's economic potential, it should be noted that the idea of RILA also represents the historical fulfillment of the foreign policy proposal for South America designed by the statesmen of the Second Reign of the Brazilian Empire.

Since the mid-19th century, the Portuguese-speaking tropical monarchy sought not only to achieve the integration of its isolated territory, but also to seek harmonious relations with its then turbulent neighbors in the Southern Cone.

Taking advantage of the geography of the Platine region allowed the Empire not only to exercise its hegemony, but also to help sustain the stability of the then fragile Paraguay and Uruguay, allowing them to continue as viable countries. In the 21st century, with the RILA and the push for economic development in the region, the imperial plan is considered to be a reality.

Soares (2021) praises the achievements of imperial diplomacy, which he calls the "shield of Brazil", with these words:

This was the great advantage that Brazil had over other Hispanic-American countries. The advantage of a perfect "diplomatic style", based on culture, sharp political observation, geographical realities and the personal gifts of agents dispatched abroad. The Imperial Chancellery knew the geographical realities with its neighbors more thoroughly than the neighbors themselves... Brazilian diplomacy has always known how to use a profound knowledge of the geographical realities of America and a no less profound knowledge of International Law. Thus, doctrine became policy and policy became action. (SOARES, 2021, p. 334).

The plan to guarantee freedom in the Platine region had the consequence of allowing the Empire of Brazil to exercise a hegemony in which, while it presented itself as the dominant geopolitical force in the region, it also prevented the Platine countries from using local hydrography for the exclusive benefit of their nations. And that also paved the way for future integrative projects. 
Globalization presupposes an intense fluidity of people, goods and information. The idea of integration cannot and should not go unnoticed. Perhaps the dream of Latin American integration, coined a long time ago, will come true in the coming years with the construction of RILA.

\section{FINAL CONSIDERATIONS}

Everywhere, the regional integration is a challenge that demands the smart development of international politics. That's because they need to foment the local growing utilizing the available resources in their own time and space.

In the case of South America, the Platine Basin shows itself as a big tool to promote this integration. The dynamics of the Brazil-Paraguay relationship is built considering the Basin, and the creation of the RILA was an interesting way to operate the integrative process, allied with the economic growth and social development between the two nations.

With those premises, this paper presented that the RILA itself is the coronation of a geopolitical conceptions already developed by the statesmen of Imperial Brazil, in the senses that they sought the free navigation within the Platine Basin as a way to obtain not only the political hegemony in the Southern Cone, but also to integrate the so far isolated national territory, provided that some of its corners were only reachable by fluvial routes. Above all, the Empire envisioned Brazil, though some of its ideas only became functional in the subsequent centuries, expanding them to promote the regional development.

The discussion was opened with an analysis about the regional geography in the part of the Platine Basin that waters Brazil and Paraguay. Establishing a concept of border, it was made the link by which such concept dialogues with the regional situation of Brazil and Paraguay, describing from common cultural peculiarities to social characteristics of the shared limits between the two nations, pointing the economic importance of hydrography for the region, fundamental topic for the comprehension of the following chapters.

Then, the work proceeded to its historical part, recalling the formation of the Second Reign of the Empire of Brazil. Starting from a quick analysis of the institutional formation of the South American monarchy, the paper went through the topic of the Brazilian diplomatical challenges related to the Platine Basin. Comprehending its objectives as the territorial occupation and defense, communication with isolated provinces and the free navigation sustenance at the Plata River, it made itself understandable the course of imperial diplomatic actions at the region bordering Paraguay. The War of the Triple Alliance, a defining factor for the relations between Brazil and Paraguay, was a momentary shock, but it had the consequence of securing the Brazilian position at the Plata River as a dominating force. Considered successful by many historians, the imperial diplomacy not only accomplished its objectives, but launched the bases for the geopolitical conceptions of development capable of encompass the entire region, and would be operationalized in the following centuries, a thesis completed and defended at the following chapter.

The article's last section treated about the RILA, with all the potentiality to promote the Latin American integration, especially between Brazil and Paraguay. It is an ambitious project which aims to the economic promotion between the involved countries, and that it utilizes the Platine hydrography to allow the flow of exportable production of the region's nations, notably Paraguay, a landlocked country. The promised profitability by all the transport and tourism 
infrastructure investments for the RILA makes the region a developing pole that can benefit all countries included in the project.

This presentation aimed to demonstrate that the own conception of the RILA has its origins in the geopolitical objectives traced by the diplomats of Imperial Brazil. Containing the unstable Hispanic-American countries at South America, Brazil sought to sustain the regional equilibrium by maintaining the freedom of navigation at the Platine Basin, by means that not only secured the monarchy's own interests, but also did not prevent it's free access by the regions watered by the Plata River. What was born as an intention of internal integration and border protection of the isolated province of Mato Grosso evolved to concepts able to benefit all the region's countries by a concrete infrastructure project made feasible centuries later. It's not an exaggeration of reality to sustain that the Empire has envisioned Brazil like it is, granting solid bases for the Brazilian positioning in front of its neighbors.

Even if the solution of border problems between Brazil and Paraguay depends on autonomous conjunctures of political, juridical, social or economic origin, it is undeniable that the RILA provides a viable path to the stimulation of regional development, and that a good part of those problems can be solved with the valorization of Brazilian diplomatic thought from the times of the Second Reign, privileging the freedom of locomotion at the Platine Basin and the sustenance of all the autonomies of neighboring countries, which are also RILA promises.

\section{REFERENCES}

BARRIO, C. O. L. O Império do Brasil e a política de intervenção no rio da Prata (1843-1865). Brasília, DF: FUNAG, 2018.

BECKER, B. K. Amazônia: geopolítica na virada do III milênio. Rio de Janeiro: Garamond, 2007.

BRASIL. Constituição da República Federativa do Brasil. Brasília, DF, 1988. Available at: https://www. planalto.gov.br/ccivil_03/Constituicao/Constituicao.htm. Access on: 25 May 2021.

CALMON, P. História da civilização brasileira. Brasília, DF: Senado Federal, 2002.

CALÓGERAS, J. P. Formação histórica do Brasil. Brasília, DF: Senado Federal, 2009.

DORATIOTO, F. F. M. O Brasil do Rio da Prata (1822-1994). 2. ed. Brasília, DF: FUNAG, 2014.

DORATIOTO, F. F. M. Maldita Guerra: nova história da Guerra do Paraguai. 2. ed. São Paulo: Companhia das Letras, 2002.

FAUSTO, B. História do Brasil. São Paulo: Editora da Universidade de São Paulo, 1995.

GOES FILHO, S. S. As fronteiras do Brasil. Brasília, DF: FUNAG, 2013.

OLIVEIRA LIMA, M. Formação histórica da nacionalidade brasileira. Brasília, DF: Senado Federal, 2012.

PAIXÃO, R. O. Turismo na fronteira: identidade e planejamento de uma região. Campo Grande: Editora UFMS, 2006.

POLÓN, L. C. K. Brasil-Paraguai: considerações sobre a "fronteira do consumo". Tempo da Ciência, Toledo, v. 22, n. 44, p. 71-77, 2015. Available at: http://e-revista.unioeste.br/index.php/tempodaciencia/article/ view/12933/8935. Access on: 24 May 2021. 
SOARES, Á. T. O drama da tríplice aliança (1865-1876). Brasília, DF: FUNAG, 2021.

SOUZA, E. B. C.; GEMELLI, V. Território, região e fronteira: análise geográfica integrada da fronteira Brasil/ Paraguai. Revista Brasileira de Estudos Urbanos e Regionais, Rio de Janeiro, v. 13, n. 2, p. 101-16, 2011. Available at: https://www.redalyc.org/pdf/5139/513951688008.pdf. Access on: 24 May 2021.

SILVA, J. M. Fronteiras Guaranis. 2. ed. Campo Grande: Instituto Histórico e Geográfico de Mato Grosso do Sul, 2003.

SUNAKOZAWA, L. F. J.; REYNALDO, G. O. A Rota de Integração Latino-americana (RILA) diante da globalização: a necessidade urgente da pavimentação jurídica transnacional e territorial. In: FEITOSA, A.; FRANCESCHINI, B.; SILVA, R. B.; BRITO, R. D. (Orgs.). Perspectivas de Direito Contemporâneo. Rio de Janeiro: Grupo FGB-Pembroke Collins, 2019. p. 706-21.

TORRES, J. C. O. A democracia coroada. Brasília, DF: Câmara dos Deputados, 2017.

VARGAS, F. A. Formação das fronteiras latino-americanas. Brasília, DF: FUNAG, 2017.

YEGROS, R. S.; BREZZO, L. M. História das relações internacionais do Paraguai. Brasília, DF: FUNAG, 2013.

ZUGAIB, E. A hidrovia Paraguai-Paraná. Brasília, DF: FUNAG, 2007.

\section{About the authors:}

Luiz Jeha Pecci de Oliveira: Masters student in Local Development at Dom Bosco Catholic University (UCDB). Specialist in Administrative Law at the Unyleya College. Graduated in Law at UCDB. E-mail: luizpecci97@gmail.com, Orcid: https://orcid.org/0000-0003-4102-7587

Gabriela Oshiro Reynaldo: Doctorate student and Master's Degree in Local Development from the Dom Bosco Catholic University (UCDB). Graduated in Geography at the State University of Mato Grosso do Sul (UEMS) and Law at UCDB. Teacher of Geography and Current Affairs at schools from the private sector in Campo Grande, MS, as well as in prepping courses for military exams, focusing at the ESPCEX exam. Voluntary researcher in extension and researching groups linked to the Route of Latin American Integration (RILA). E-mail: oshiro.gabriela@hotmail.com, Orcid: http://orcid.org/0000-0003-0575-447X

Maria Augusta de Castilho: PhD in Linguistics at the University of São Paulo (USP). Doctorate in Social Sciences at USP. Currently, is a professor of the History Major department and of the Post-Graduate Program in Local Development - Masters/Doctorate at the Dom Bosco Catholic University (UCDB), also being head of the History's Major Department Laboratory. E-mail: maugusta@ucdb.br, Orcid: https://orcid.org/0000-0001-5235-3164 
